Gifkins, Jess, Jarvis, Samuel ORCID:

https://orcid.org/0000-0002-1987-9751 and Ralph, Jason (2019) Brexit and the UN Security Council: declining British influence? International Affairs, 95 (6). pp. 1349-1368.

Downloaded from: http://ray.yorksj.ac.uk/id/eprint/4152/

The version presented here may differ from the published version or version of record. If you intend to cite from the work you are advised to consult the publisher's version: http://dx.doi.org/10.1093/ia/iiz205

Research at York St John (RaY) is an institutional repository. It supports the principles of open access by making the research outputs of the University available in digital form. Copyright of the items stored in RaY reside with the authors and/or other copyright owners. Users may access full text items free of charge, and may download a copy for private study or non-commercial research. For further reuse terms, see licence terms governing individual outputs. Institutional Repository Policy Statement

\title{
RaY
}

Research at the University of York St John

For more information please contact RaY at ray@yorksj.ac.uk 


\section{Brexit and the United Nations Security Council: Declining British Influence?}

'June the 23rd was not the moment Britain chose to step back from the world. It was the moment we chose to build a truly Global Britain'.

Theresa May reflecting on the Brexit vote ${ }^{1}$

Years before the UK voted to leave the EU a thought experiment postulated that the fallout for the UK if it withdrew from the EU would be 'severe'. ${ }^{2}$ Since the vote Sir Simon McDonald, as head of the Foreign and Commonwealth Office (FCO), described Brexit as 'The biggest thing that we have ever undertaken in peace time'.$^{3}$ It is clear that Brexit represents a significant upheaval within the UK, within the EU, and for EU states - particularly those with substantial trade relationships with the UK. ${ }^{4}$ But what impact has the decision to leave the EU had for the UK within the United Nations Security Council? The connection may not be immediately obvious, given that the UK's seat within the Security Council is permanent. The UK would need to consent to its own removal from the UN Security Council and in that sense, its institutional position is secure, but what about its capacity to use its position to both advance its interests and to help to maintain international peace and security?

Thus far the literature on Brexit at the UN has focused on other organs such as the Human Rights Council and nuclear weapons forums ${ }^{5}$, and key UN commentator Richard Gowan has lamented that 'Brexit's impact at the UN has not been a subject of much speculation outside specialist circles' ${ }^{6}$. Others agree that 'One of the underdiscussed aspects of Brexit is the

\footnotetext{
${ }^{1}$ Theresa May, 'Theresa May's Brexit Speech: A Global Britain', The Spectator, 2017, https://blogs.spectator.co.uk/2017/01/theresa-mays-brexit-speech-global-britain/.

2 Jamie Gaskarth, 'Strategizing Britain's role in the world', International Affairs, 90:3, 2014, p.568.

3 'Inside the Foreign Office', Episode 2: A Brave New World, 2018, directed by Michael Waldman.

${ }^{4}$ Richard G. Whitman, 'The UK's European diplomatic strategy for Brexit and beyond', International Affairs 95:2, 2019, pp. 383-404.

${ }^{5}$ Megan Dee, and Karen E. Smith, 'UK diplomacy at the UN after Brexit: Challenges and Opportunities', The British Journal of Politics and International Relations, 19:3, 2017, pp. 527-542.

${ }^{6}$ Richard Gowan, 'Separation Anxiety: European Influence at the UN after Brexit', European Council on Foreign Relations, 2018,

http://www.ecfr.eu/publications/summary/separation_anxiety_european_influence_at_the_un_after_brexit.
} 
immense damage it will do to Britain's standing as a global foreign policy player' ${ }^{7}$ After the vote, the UK's then Ambassador to the United Nations, Matthew Rycroft, said 'my job has just got a lot bigger' because 'the UK's window into the world will be even more through the United Nations'.$^{8}$ That implies the withdrawal from one multilateral forum (the EU) does not harm, but merely concentrates, UK diplomacy in another (the UN). We investigate whether that is the case by looking specifically at how the UK wields influence in the UN Security Council. There is a conclusion among those who have examined the wider UN system that Brexit does indeed challenge the UK's influence. ${ }^{9}$ We ask whether that conclusion holds for UK influence at the Security Council.

The UK does not wield influence at the Council in a way that might be expected of a 'great power'. It cannot draw on material resources in the way the US or (increasingly) China can; and given the questions that raises about the UK's status as a permanent member, the UK has been reluctant to influence the Council by using its veto. ${ }^{10}$ The UK instead relies on its diplomatic expertise, reputation and networks to influence the Council, and this therefore is the focus of our analysis. Drawing on the recent 'practice turn' in International Relations theory, we explain how these resources can be understood as a kind of 'capital' that enables the UK to 'purchase' influence. Brexit, we argue, risks devaluing that capital. More

\footnotetext{
${ }^{7}$ Denis MacShane, 'Brexit and the Decline of British Foreign Policy', Strategic Europe, Carnegie Europe, 2017, http://carnegieeurope.eu/strategiceurope/72665.

8 UNA-UK, 'Ambassador Matthew Rycroft discusses UK priorities for UN at parliamentary meeting', 2016, https://www.una.org.uk/news/ambassador-matthew-rycroft-discusses-uk-priorities-un-parliamentarymeeting.

${ }^{9}$ See for example; Dee and Smith, 'UN diplomacy at the UN'; Amelia Hadfield, 'Britain Against the World? Foreign and Security Policy in the "Age of Brexit"', in Benjamin Martill and Uta Staiger, eds, Brexit and Beyond: Rethinking the Futures of Europe, (London: UCL Press, 2018); Christopher Hill, 'Turning Back the Clock: The Illusion of a Global Political Role for Britain', in Martill and Staiger eds, Brexit and Beyond; MacShane, 'Brexit and the Decline of British Foreign Policy'; Nicholas Wright, 'Brexit \& the Re-making of British Foreign Policy', UCL European Institute, 2017, https://www.ucl.ac.uk/european-institute/ei-publications/working-paperforeign-policy.pdf.

${ }^{10}$ While permanent membership is associated with the Second World War settlement, it is normatively underpinned by a need to bind the contemporary great powers to collective security arrangements that use their resources to deliver other public goods or the 'governance' objectives of wider international society. This norm suggest that permanent membership should shift as power does. For discussion, see Jason Ralph, Jess Gifkins and Samuel Jarvis, 'The UK's Special Responsibilities at the United Nations. Diplomatic Practice in Normative Context', British Journal of Politics and International Relations forthcoming. On the UK reluctance to use its veto see Mahbubani K. (2016) Council Reform and the Emerging Powers. In: von Einsiedel S, Malone DM and Stagno Ugarte B (eds) The UN Security Council in the 21st Century. Boulder: Lynne Rienner, 2016, 159; Tardy T and Zaum D. (2016) France and the United Kingdom in the Security Council. In: von Einsiedel S, Malone DM and Stagno Ugarte B (eds) The UN Security Council in the Twenty-First Century. Boulder: Lynne Rienner Publishers 2016, 130.
} 
specifically, Brexit risks weakening the networks that act as diplomatic multipliers and this damages the country's reputation as an effective leader, which will reduce its influence. While we focus on these aspects of leadership, we do not ignore the material impact that Brexit will have on UK influence at the Council. Indeed, if, as others have argued, it is easier to induce followership when one contributes a fair share of the material burden, then future UK leadership is contingent on it contributing more material resources to Security Council mandated operations. ${ }^{11}$ That will be difficult given the economic disruption of Brexit and the increased competition for fewer budgetary resources. ${ }^{12}$

These risks are explored via two case studies: Somalia and Yemen. These cases were selected as timely examples of country situations where the UK has acted as the 'penholder', UN vernacular that identifies the state to lead the process of drafting resolutions. Given this enhanced role in coordinating the Council's response, these cases provide insight into how the UK's changing relationship with the EU effects the sources of its influence on the Council. The Somalia case study, for instance, shows how the UK has been able to align EU and UN policy such that the material resources of the former have enabled the UK to achieve its goals in the latter, and to thereby properly discharge its responsibilities as a permanent member. More specifically, the UK's diplomatic leadership in the Council, which delivered a legal mandate for the African Union peacekeeping mission, was backed up by EU material resources so that the force could deliver practical progress on the ground. Here the EU helped to offset the material burden of UK leadership.

The Yemen case study highlights tensions between the UK's role as 'penholder' on Yemen and its substantial trade relationship with Saudi Arabia which is a party to the conflict. ${ }^{13}$ This study illustrates the difficulty diplomats on the Council face in defending their reputation as leaders on humanitarian and human rights issues when what is required to do that clashes with the national interest in promoting UK business interests. This of course is a perennial problem, one that existed long before Brexit. It is discussed here to illustrate how the increased interest in new trade deals with partners outside the EU, some of whom are alleged to be complicit in

\footnotetext{
11 Jason Ralph, Jess Gifkins and Sam Jarvis, 'The UK's special responsibilities at the United Nations. Diplomatic Practice in Normative Context', British Journal of Politics and International Relations forthcoming.

${ }^{12}$ Linda Yueh, 'Britain's Economic Outlook after Brexit' Global Policy 8:24 2017, 54-61.

${ }^{13}$ Andrew Mitchell, 'Britain is Complicit in Saudi Arabia's War on Yemen', The Guardian, 13 June 2018, https://www.theguardian.com/commentisfree/2018/jun/13/britain-complicit-saudi-arabia-war-yemenhodeidah.
} 
humanitarian and human rights abuses, exacerbates that dilemma. Bringing that back to the UK's influence on the Council, we illustrate how a perception that Britain post-Brexit will put trade before values can harm the UK reputation as a leading influence in the area where it has long staked that claim: humanitarian and human rights.

Whilst these two cases studies cannot encapsulate the full range of UK activity in the Security Council, they do provide significant examples of how the UK'sinfluence in that forum could be limited by Brexit. Our analysis proceeds in four section. The first draws on 'practice theory', and in particular the concept of 'capital', to highlight the way diplomats wield influence in the Council. We draw on this literature to explain our methods for interpreting the working practices of the Security Council and delineating markers of diplomatic influence. The second and third sections draw on original interview data to understand how UK diplomats in particular have cultivated a reputation for competence and influence. The fourth section locates the two case studies in the context of the government's insistence that the UK will remain an 'open, outward-looking and confident state' that can wield influence on the world stage through its position on the UN Security Council.

\section{Diplomatic practice at the United Nations}

Diplomats are responsible for much of the enactment of international politics, yet they often have different perspectives on what constitutes influence within the UN when compared to the traditional perspectives offered by International Relations (IR) theory. ${ }^{14}$ The recent 'practice turn' in IR promises to close this gap. ${ }^{15}$ To understand a state's capacity for influence we need to consider both its structural position in the international system and the 'competence' of its diplomats to master and mould the practices that structure state interactions. 'Practice theory' demands an interpretivist approach to data gained through, for example, ethnographic study or elite interviews; and for this project we conducted elite

\footnotetext{
${ }^{14}$ Rebecca Adler-Nissen, 'Conclusion: Relationalism or why diplomats find International Relations theory strange', in Ole Jacob Sending, Vincent Pouliot, and Ivan B. Neumann, eds, Diplomacy and the Making of World Politics, (Cambridge: Cambridge University Press, 2015); and Vincent Pouliot, International Security in Practice: The Politics of NATO-Russia Diplomacy, (Cambridge: Cambridge University Press, 2010).

${ }^{15}$ Iver B. Neumann, 'Returning Practice to the Linguistic Turn: The Case of Diplomacy', Millennium: Journal of International Studies, 31:3, 2002, p. 628.
} 
interviews with current and former diplomats and asked them what constitutes influence within the UN Security Council. ${ }^{16}$ While some mentioned traditional metrics of power - such as military strength and economic weight - these were not the primary capacities they highlighted. From the perspective of a diplomat, the most important qualities for exerting influence within the Security Council were reputation and positions of authority in negotiations. In this regard, influence is understood here in terms of the ability of diplomats to demonstrate competence and thus make use of their mastery of established practices to achieve their aims ${ }^{17}$ For the UK in particular, we argue that its declining material power is not the key source of its influence in the Council, instead our interview data suggests that its reputation for competence and its governance role in the Council, allow it to have a far more significant influence than its material capabilities would initially indicate.More generally, state 'strategies' are determined by capitals and 'tactics' for achieving the goals they set are determined by permanent missions in New York. ${ }^{18}$ Both aspects are important, and without judgment and skill in both aspects (as well as alignment between them) a state will struggle to achieve its goals within the UN Security Council. As Barnett and Finnemore stress, we need further research on the relationship between a state's position in global affairs and its capacity for influence inside the UN. ${ }^{19}$ They highlight diplomatic capacity as an underresearched area with the potential to help explain how some states are able to be influential in the UN and others are not. Practice theory offers scope for a re-balancing of IR whereby traditional metrics of power are not discounted but are considered alongside questions of reputation and diplomatic competence. As such, this analysis of Brexit considers risks to the UK's traditional metrics of power alongside risks to its diplomatic capacities.

Reputation and capacity for influence are based on perceptions which meant we needed to interview people (with direct professional experience) about their perceptions of the UK's performance in the UN and any changes to this after the Brexit referendum. For this project

\footnotetext{
${ }^{16}$ Vincent Pouliot, 'Methodology', Rebecca Adler-Nissen ed, Bourdieu in International Relations, (London, Routledge, 2013), pp. 45-58.

${ }^{17}$ Rebecca Adler-Nissen and Vincent Pouliot, 'Power in practice: Negotiating the international intervention in Libya', European Journal of International Relations 20:4, 2014, pp.895-896.

${ }^{18}$ Author Interview \#21, conducted in London, 7 November 2018; and Author Interview \#27, conducted via phone, 6 January 2019.

${ }^{19}$ Michael N. Barnett and Martha Finnemore, 'Political Approaches', in Thomas G. Weiss and Sam Daws eds, The Oxford Handbook on the United Nations, 2nd ed, (Oxford: Oxford University Press, 2018), pp.72-73.
} 
we have interviewed 29 people which includes 10 individuals based in London and 18 individuals based in New York (and 1 based elsewhere). ${ }^{20}$ Interviewees include three former British Ambassadors to the United Nations, UK officials, EU officials, diplomats within UN permanent missions, and individuals from the epistemic community around the United Nations. We used semi-structured interviews which enabled both repetition of questions to people in different roles and the flexibility to follow up with additional questions from material raised during the interview. Reflecting on this methodological approach and its limits, it is important to also highlight that interviews will always provide a particular reading of the situation and thus must be treated with some caution, in this case one may argue that those working within an international institution are unlikely to approve of a state's withdrawal from another key regional institution. However, as highlighted by Rebecca AdlerNissen, 'Interviews are important, not because informants know the 'big-T' truth, but because their particular truths are valuable'. ${ }^{21}$ The perceptions of our interviewees matter because they are, or were, directly involved in multilateral diplomacy including, for some, negotiating with or for the UK. In this sense, whilst each interviewee may have a different stake in the outcome of Brexit, their views still provide evidence of how key actors involved in UN diplomacy perceive the UK's status and reputation for influence and the extent to which their own perceptions may have changed as a result of the Brexit vote.

It is also important to understand that Brexit is not happening in a vacuum. The UK's vote to leave the EU is regularly discussed in tandem with the US election of President Trump; as an expression of frustration by those left behind by globalization. ${ }^{22}$ This connects to broader trends on the decline of the liberal world order, through both a crisis of authority from those who usually champion liberalism, such as the US and UK, and through the rise of less liberal states. ${ }^{23}$ Within the UK, the referendum vote took place within the context of longer-term

\footnotetext{
${ }^{20}$ We contacted each state that served on the Security Council since the Brexit referendum 2016-2018-a total of 25 states. Some were willing to be interviewed and some declined or did not respond. Most interviewees requested anonymity.

${ }^{21}$ Rebecca Adler-Nissen, 'Towards a Practice Turn in EU Studies: The Everyday of European Integration', Journal of Common Market Studies, 54:1, 2016, p.97.

${ }^{22}$ See for example Hugh Gusterson, 'From Brexit to Trump: Anthropology and the Rise of Nationalist Populism', American Ethnologist, 44:2, 2017, pp. 209-214.

${ }^{23}$ Constance Duncombe, and Tim Dunne, 'After Liberal World Order', International Affairs, 94:1, pp. 25-40; see also Beate Jahn, 'Liberal internationalism: historical trajectory and current prospects', International Affairs 94:1, 2018, pp. 43-61.
} 
trends of British decline. ${ }^{24}$ However, this sentiment is also self-perpetuating, with Brexit increasing the perception among other states that the UK is in decline. ${ }^{25}$ British decline and Brexit become understood as complementary. As explained by lan Martin, former Special Representative to the UN Secretary-General; 'In New York [at the UN], the decline in UK influence is palpable. It's partly Brexit, but not only'. ${ }^{26}$ Having to work within the context of the UK's relative decline is not new for UK diplomats, including those at the UN. Indeed, UK activism on what Bosco calls the 'governance' issues of the Council (including humanitarian and human rights issues) is considered a way of countering the argument that UK's relative decline does not warrant a permanent place within a 'great power concert'. ${ }^{27}$ This is further evidence that diplomatic influence is separate to traditional great power metrics, but it also shows how the UK's standing is linked to the governance side of the Security Council's agenda, and especially its influence on the humanitarian and human rights issues, which increasingly dominate that agenda.

\section{What does it take to be influential within the UN Security Council?}

Within multilateral diplomacy, the capacity to influence negotiations comes from political capital. Political capital is a form of power which 'is derived from the trust expressed in a form of credit that a group of followers places in them. Obtained through social competences, reputation and personal authority'. ${ }^{28}$ It is a form of social capital, which refers to 'the sum of all the resources, actual or virtual, that accrue to an individual or a group by virtue of possessing a durable network of more or less institutionalized relationships of mutual acquaintance and recognition'. ${ }^{29}$ As such, political capital is relational rather than possessed, and fluid rather than fixed, which means that to have political capital to draw on, actors need

\footnotetext{
${ }^{24}$ Gaskarth, 'Strategizing Britain's role'.

25 Daniel Gill and James Oates, 'Britain's Place in the World: A Force for Good?', Wilton Park, 2017, https://www.wiltonpark.org.uk/wp-content/uploads/WP1597-Report.pdf.

${ }^{26}$ Michael Day, 'Britain's influence in the United Nations is fading', i Newspaper, 2018, https://inews.co.uk/news/world/britains-influence-in-the-united-nations-is-fading/.

27 David Bosco, 'Assessing the UN Security Council: A Concert Perspective', Global Governance, 20:4, 2014, pp. 545-61; Tardy and Zaum, France and the United Kingdom in the Security Council, p.121.

${ }^{28}$ Rebecca Adler-Nissen, 'The Diplomacy of Opting Out: A Bourdieudian Approach to National Integration Strategies', Journal of Common Market Studies, 46:3, 2008, p.670.

29 Pierre Bourdieu, and Loïc Wacquant, An Invitation to Reflexive Sociology, (Chicago: University of Chicago Press, 1992) p. 119.
} 
to continually invest in their skills, relationships, and reputation. To develop and maintain political capital, a state needs to be seen as an actor of good faith and in good standing. As Bourdieu argued, 'This supremely free-flowing capital can be conserved only at the cost of unceasing work, which is necessary both to accumulate credit and to avoid discredit'. ${ }^{30}$ States need to continually invest in their skills, relationships, and reputation to maintain their political capital. This is key for Brexit, as any decrease in the UK's political capital needs to be met with additional political, diplomatic and financial investments to maintain its current capacity for influence (let alone to expand its capacity for influence).

In interviews of those elites familiar with practices of the Council, we asked what it takes to be influential within the UN Security Council specifically, and then asked them to reflect on how the UK's changing circumstances might effect its influence there. Interestingly, the attributes typically associated with power within IR - military strength and economic resources - were mentioned but less frequently or prominently than intangible qualities of reputation and diplomatic skill. ${ }^{31}$ There were three attributes that were mentioned most frequently by interviewees. ${ }^{32}$ First, 'penholding' which is a process that has emerged in the Security Council over the past decade whereby a state takes political ownership for leading drafts on a specific topic. ${ }^{33}$ This practice gives penholders considerable influence as they can interpret the situation, frame options, and they even have considerable capacity to determine when and whether there is a draft.

Second, the diplomatic skill of a UN permanent mission is an important source of political capital. Diplomats who are trusted, respected, and have a good 'feel for the game' in terms of when and how far to push things have much greater capacity for influence. There was clear recognition from interviewees that even within the United Nations, the Security Council is a unique body and it takes time to learn how to be influential in this environment. ${ }^{34}$ Third, the

\footnotetext{
${ }^{30}$ Cited in Adler-Nissen, 'The Diplomacy of Opting Out' p.670.

${ }^{31}$ On this point, see also Adler-Nissen, 'Conclusion'.

32 The difference in influence between permanent and elected members was taken as a given by interviewees, and sometimes referred to in passing.

${ }^{33}$ On penholding see; Jason Ralph and Jess Gifkins, 'The purpose of United Nations Security Council practice: Contesting competence claims in the normative context created by the Responsibility to Protect', European Journal of International Relations, 23:3, 2017, pp. 630-653; and Izadora Xavier do Monte, 'The Pen is Mightier than the H-Bomb, Interventions 18:5, 2016, pp. 669-686.

${ }^{34}$ On this point, see also, Gert Rosenthal, Inside the United Nations: Multilateral Diplomacy up Close, (Abingdon and New York: Routledge, 2017).
} 
personal qualities of a states' permanent representative can enhance (or decrease) the influence that states are able to exert. As one interviewee described, 'we have always benefitted from having good people at the UN and good permanent representatives. That is important as that personal element is much more important than you might think in the way stuff works, especially in New York'. ${ }^{35}$ Consequently, the focus of the interviews were informed by practice based research which has emphasised the importance of gathering detailed accounts of individual actors perceptions and actions in order to help highlight broader dynamics and power structure, which may be "hidden in 'macro' accounts of UNSC decision-making". ${ }^{36}$ Our findings also help to confirm recent research which corrects the overlooked role that individuals play within UN diplomacy, such as leadership by former French Permanent Representative Jean-Marc de la Sablière on Children and Armed Conflict. ${ }^{37}$

\section{The UK's political capital at the UN}

If the above qualities and attributes tell us what it takes to be influential in the UN Security Council in general, what does this mean for the UK in relation to the decision to leave the EU? As noted, the UK, like France, has been among the most activist states on the Security Council, especially on the 'governance' side of the agenda. These two powers have not cast their veto since the 1980s, conscious that such an action would draw attention to what is considered in some quarters as an indefensible membership of a 'great power concert'. ${ }^{38}$ In these circumstances, an active approach to governance issues, especially humanitarian and human rights issues, is often seen as an attempt to legitimize its continued occupation of a permanent seat. ${ }^{39}$ Pursuing humanitarian and human rights causes at the Council is not just a values question, therefore; it is central to the UK's reputation as a competent and responsible member of the Council, which in turn enables UK diplomats to defend the

\footnotetext{
${ }^{35}$ Author Interview \#15, conducted in London, 23 August 2018.

${ }^{36}$ Ingvild Bode, 'Reflective practices at the Security Council: Children and armed conflict and the three United Nations', European Journal of International Relations, 24:2, 2018, p.312.

${ }^{37}$ Bode, 'Reflective Practices', pp.293-318.

38 Kishore Mahbubani, 'The Permanent and Elected Council Members', in David M. Malone ed, The UN Security Council: From the Cold War to the 21st Century, (Boulder and London: Lynne Rienner Publishers, 2004), pp. 253-266.

${ }^{39}$ Sebastian von Einsiedel, David M. Malone and Bruno Stagno Ugarte, 'The UN Security Council in an Age of Great Power Rivalry', Working Paper Series, 04, United Nations University, 2015, https://i.unu.edu/media/cpr.unu.edu/attachment/1569/WP04_UNSCAgeofPowerRivalry.pdf.
} 
national interest in legitimizing its permanent status. Here, then, the 'strategic' and the 'tactical' merge. If the government in London has a strategic interest in defending the UK's standing at the Council, then the tactical advantage UK diplomats in New York have in leading on governance issues such as humanitarian and human rights issues should be seen as an asset that advances the national interest. To withdraw from leadership in these areas, or to lead in a way that is seen to advance the national interest ahead of the humanitarian and human rights concerns of the Council will damage its influence.

Indeed, the British government has stressed that its commitment to the UN will remain at the core of its foreign policy post-Brexit. ${ }^{40}$ Interviewees also confirm that there is a division of labour in UN diplomacy whereby the government in London is responsible for developing the strategies and goals and the permanent mission in New York is responsible for developing tactics on how to achieve these goals. ${ }^{41}$ As such both have key roles to play in determining how influential a state can be by setting the ambition and initiatives in capitals and the approach and techniques that will be used to achieve these goals in New York. ${ }^{42}$ To assess the impact of the Brexit referendum on the UK's capacity for influence in the UN we need to consider both the political capital of the state and the permanent mission alongside ways that these have been (or could be) impacted by Brexit.

On penholding - which interviewees named most frequently as a key metric of influence the UK is a dominant and effective actor. ${ }^{43}$ In 2019, there were 39 agenda items in the Security Council with penholders and the UK was penholder for 12 agenda items representing almost one third of the total when an equal distribution would be one fifteenth. ${ }^{44}$ The UK is penholder for high profile conflicts such as Myanmar and Yemen, as

\footnotetext{
${ }^{40}$ Foreign \& Commonwealth Office, 'Foreign policy in Changed World Conditions - Foreign and Commonwealth Office, FPW0027, 2018,

http://data.parliament.uk/writtenevidence/committeeevidence.svc/evidencedocument/internationalrelations-committee/foreign-policy-in-changed-world-conditions/written/79900.pdf

${ }^{41}$ Author Interview \#21; and Author Interview \#27.

42 There is also variance on how much leeway individual permanent missions have from their capital, with the UK considered to have a high degree of leeway.

${ }^{43}$ The caveat given regularly in interviews on this point was British penholding on Yemen which is explored later in the article.

${ }^{44}$ Security Council Report, Lead Roles within the Council in 2019: Penholders and Chairs of Subsidiary Bodies, 2019, https://www.securitycouncilreport.org/monthly-forecast/2019-02/lead-roles-within-the-council-in2019-penholders-and-chairs-of-subsidiary-bodies.php.
} 
well as prominent thematic areas such as the protection of civilians in armed conflict, and Women, Peace and Security.

On our other two key metrics of influence - diplomatic skill and reputation of permanent representatives - our findings confirm Adler-Nissen and Pouliot's conclusion that the UK delegation in New York is 'widely recognized in New York for its superior skills in many legal technicalities that often bog down the Council'. ${ }^{45}$ As one interviewee stressed; 'the UK is clearly at the top of the league' in terms of its diplomatic machinery. ${ }^{46}$ An interviewee from a P5 permanent mission in New York echoed this claim: 'there's obviously a very strong diplomatic corps, so in terms of professionalism and expertise they're not outdone on that'. ${ }^{47}$ This is not a recent phenomenon; the comments of our interviewees align with an earlier interview of Lord Malloch-Brown who described the UK as having 'first-class ambassadors and first-class staff in New York, sending some of our best diplomats, you know just working the UN with a seriousness that, say, the US didn't do'. ${ }^{48}$

The UK delegation is one of the largest at the UN, it is relatively successful in placing nationals in key positions in the Secretariat, which brings with it access and influence, and of course the UK's veto power can influence informal discussions, tilting the consensus toward the UK position. ${ }^{49}$ The fact that Security Council negotiations are normally conducted in English gives UK diplomats advantages in finessing language over diplomats from non-English speaking countries. ${ }^{50}$ The UK performs well on all three of the key metrics of influence indicated by our interviewees.

While the UK's permanent mission (UKMIS) has a high level of political capital within the New York diplomatic milieu, these skills and expertise cannot be taken for granted, they need to be maintained through continued high-level investments in the British foreign service. Membership of the EU, along with strong diplomacy at the UN, are seen as key qualities for

\footnotetext{
${ }^{45}$ Rebecca Adler-Nissen and Vincent Pouliot, 'Power in practice: Negotiating the international intervention in Libya', European Journal of International Relations 20:4, 2014, p.898.

${ }^{46}$ Author Interview \#23, conducted in New York, 11 December 2018.

${ }^{47}$ Author Interview \#24, conducted in New York, 12 December 2018.

${ }^{48}$ Gaskarth, 'Strategizing Britain's role', p.572.

${ }^{49}$ Author Interview \#21; and Author Interview \#26, conducted in New York, 14 December 2018.

50 Jeffery Everett, 'Organizational Research and the Praxeology of Pierre Bourdieu', Organizational Research Methods 5:1, 2002, pp. 56-80.
} 
the UK in maintaining its position as an influential actor abroad. ${ }^{51}$ Many have pointed to the need for greater investment in the UK's UN capacity in the context of Brexit. ${ }^{52} \mathrm{~A}$ freedom of information request showed that since the 2016 Brexit referendum the Foreign and Commonwealth Office (FCO) had created more than 250 new roles in London and abroad to support the UK leaving the EU. ${ }^{53}$ Compared to other departments within the British civil service however, the FCO has seen some of the smallest increases since $2016 .{ }^{54}$ The FCO budget was described in a 2018 report by a British parliament Select Committee as 'far too low' and as 'hollowed out'. ${ }^{55}$ Furthermore, it is important to highlight these cuts in the wider context of austerity in the UK, which saw the Foreign Office lose more than a quarter of its budget in real terms during the coalition's five-year term in office. ${ }^{56}$ This underfunding in the run up to the Brexit vote significantly exacerbates the challenge the UK faces in being able to shift its influence outside of the EU. Consequently, whilst the UKMIS has a high level of political capital to draw on financial and political investment in UKMIS will need to be maintained or increased as the UN becomes more important to UK global strategy.

While the UK has considerable political capital 'in the bank' as it exits the EU the reputational costs of Brexit are stark. We were told that 'the UK's reputation has been depleted and degraded by this' ${ }^{57}$ and that the UK's 'reputation as a competent and effective international

\footnotetext{
${ }^{51}$ Gaskarth, 'Strategizing Britain's role'.

${ }^{52}$ Foreign Affairs Committee, 'Oral Evidence: The UK's Influence in the UN', HC675, 19 December, House of Commons, 2017.

http://data.parliament.uk/writtenevidence/committeeevidence.svc/evidencedocument/foreign-affairscommittee/the-uks-influence-in-the-un/oral/75940.html; and Foreign Affairs Committee, 'Oral Evidence: Global Britain', HC780, 6 February, House of Commons, 2018, http://data.parliament.uk/writtenevidence/committeeevidence.svc/evidencedocument/foreign-affairscommittee/global-britain/oral/78065.html; and Author Interview \#1, Questions answered via email, 31 August 2018.

${ }^{53}$ Foreign \& Commonwealth Office, 'Freedom of Information Act 2000 Request REF: 0404-18', 2018, https://assets.publishing.service.gov.uk/government/uploads/system/uploads/attachment_data/file/740897/ FOI_0404-18_Letter_FCO_UK_staff.pdf.

${ }^{54}$ Gavin Freeguard, Aron Cheung, Alice Lilly, Marcus Shepheard, Johnny Lillis, Lucy Campbell, Jenny Haigh, James Taylor and Alasdair de Costa, 'Whitehall Monitor 2019', Institute for Government, 2019, https://www.instituteforgovernment.org.uk/sites/default/files/publications/Whitehall\%20Monitor\%202019\% 20WEB_0.pdf, p.26.

${ }^{55}$ Select Committee on International Relations, 'UK Foreign Policy in a Shifting World Order', 5th Report of Session 2017-2019, 18 December, HL paper 250, House of Lords, 2018, https://publications.parliament.uk/pa/ld201719/Idselect/ldintrel/250/250.pdf.

${ }^{56}$ Kiran Stacey, Britain's Foreign Office loses direction as more cuts loom, The Financial Times, November $14^{\text {th }}$, 2014, https://www.ft.com/content/f7e4c1e8-69ab-11e4-8f4f-00144feabdc0

57 Author Interview \#27.
} 
actor has been weakened' ${ }^{58}$. Other interviewees explained that 'there is no doubt that most people regard [the UK] as less important now because of Brexit rather than more important' ${ }^{59}$ and 'If Brexit happens...in my opinion the UK's international influence will hugely diminish further' ${ }^{60}$. In addition to general perceptions of the UK, interviewees also cited specific concerns around the UK being viewed as less predictable ${ }^{61}$, distracted ${ }^{62}$, and interpreted the 2016 referendum results as 'anti-trade, anti-multilateralism, anti-values, anti-immigration' ${ }^{63}$ All of these perceptions pose significant challenges for the UK in maintaining its political capital at the UN. In contrast, some interviewees expressed skepticism concerning EU'S foreign policy, particularly those working in the areas of defense and in regions where the EU is only moderately influential. However, our interview data also suggested that there was no reason why the relationship should be viewed in zero-sum terms. While there was frustration expressed with the time that was required to formulate common positions, there was no evidence that UK interests at the UN had been harmed by them.

In addition to reputational costs caused by the Brexit decision and process, interviewees pointed to the absence of a long-term global vision of the UK's role. ${ }^{64}$ The risk is that if the British government does not provide clear new initiatives - strategies - this in turn means that UKMIS cannot develop tactics towards achieving these goals and the UK therefore does not provide leadership in the Security Council. An interviewee explained that 'The UK is now not a player on Syria. When Russia, Iran and Turkey decide they want to talk to the Europeans they talk to France and Germany. The UK is not a player in relation to Ukraine'. ${ }^{65}$ Another reflected that 'I don't think I could point to any real "UK thing" [initiative] in the UN that's really caught fire in the last couple of years'. ${ }^{66}$ These comments speak to general perceptions

\footnotetext{
58 Author Interview \#11.

${ }^{59}$ Author Interview \#15.

${ }^{60}$ Author Interview \#20, conducted in London, 7 November 2018.

61 Author Interview \#11.

62 Author Interview \#15; Author Interview \#12, conducted in New York, 26 July 2018; and Author Interview \#24.

${ }^{63}$ Author Interview \#17, conducted in New York, 4 September 2018.

${ }^{64}$ Stuart MacDonald, 'The impact of Brexit on the UK's reputation, influence and soft power', Cultural Trends, 25:4, 2016, p.283.

65 Author Interview \#20.

${ }^{66}$ Author Interview \#26.
} 
on declining influence for the UK within the UN as part of a longer term trend. Indeed, as one interviewee explained 'I see Brexit as not a cause of decline but more of a reflection'. ${ }^{67}$

Of course, it is not surprising that diplomats working in (and presumably supportive of) the UN system take this view. It is also clear that Brexiteers hold opposite views. We make no judgment, other than to note that our purpose is to investigate the influence Brexit has on the UK's capacity to influence the power structures in the UN, and to this extent the perception of diplomats whose actions constitute those structures matter. If, as is apparent, Brexit is understood by other states as emblematic of British decline then it further damages the UK's reputation as a great power and weakens the associated claim to permanent membership. The risk too is that these perceptions linger after the process of leaving the EU is over. The distraction costs of the process were evident to our interviewees. As a P5 interviewee explained 'all interactions [with the UK] are seen through the Brexit lens' ${ }^{68}$, which was a sentiment also expressed by others. ${ }^{69}$ The impact of Brexit on everyday practice too might be delayed because of the strength of informal working relationships in New York which include a kind of 'muscle memory'. ${ }^{70}$ As that fades, however, UK diplomats will have to work harder to rewire the diplomatic relationships in ways that continue to serve the UK well in its claim to permanent membership.

\section{Global Britain}

The central pillar of the UK's post-Brexit foreign policy has been the idea of 'Global Britain'. The government said that the goal of Global Britain is 'demonstrating how our country is increasingly open, outward-looking and confident on the world stage'. ${ }^{71}$ In relation to the changes brought about by leaving the EU, the FCO has described the policy as 'shorthand for our determination...to continue to be a successful global foreign policy player, and to resist any sense that Britain will be less engaged in the world in the next few years'. ${ }^{72}$ Global Britain

\footnotetext{
${ }^{67}$ Author Interview \#22, conducted in New York, 11 December 2018.

${ }^{68}$ Author Interview \#24.

${ }^{69}$ Author Interview \#22.

70 Author Interview \#24.

71 UK Government, '10th Special Report - Global Britain: Government Response to the Sixth Report of the Committee', 2018, https://publications.parliament.uk/pa/cm201719/cmselect/cmfaff/1236/123602.htm.

72 Foreign \& Commonwealth Office, 'Foreign policy in Changed World'.
} 
is pitched as enabling the UK to, once again, 'embrace the world'. ${ }^{73}$ Clear in these statements is a British goal to reassure: that Brexit is not about the UK retreating into isolationism. Beyond this sentiment however, the concept is ambiguous. Expert witnesses to parliament's Select Committee hearings on Global Britain have said 'the definition and clarity of the term "Global Britain" is not necessarily entirely clear', and 'To be frank with you, I think that many countries think that, for the time being, we have slightly lost the plot in terms of understanding where we intend to go'. ${ }^{74}$ As is evident from these witness statements there is not a clear, grounded, understanding of what Global Britain might mean, even from a UK perspective, making it difficult for the UK to project clarity of purpose abroad.

Alongside questions about precisely what 'Global Britain' means are questions about how it differs from previous foreign policy positions. The concept of 'Global Britain' has deep historical connections to previous foreign policy debates in the UK particularly those following WWII when Britain played a key role in re-imagining the post-war world order. The claim that 'Britain's horizon was global, as opposed to narrowly European like most of its Continental neighbours' was therefore reinforced by both Churchill and Atlee during the early stages of European integration. ${ }^{75}$ This was in part influenced by the special relationships the UK had with countries such as Australia, New Zealand and Canada, whereby the UK's global outlook has long related to previous ideas of empire. ${ }^{76}$ However, the sustainability of the UK's imperial ambition was already becoming untenable during this period and was only further eroded by the Suez crisis in 1956, clearly exposing the extent of UK decline as a global power and the impending break up of its empire. The unique nature of the UK's history has therefore influenced how it views its role in the world and how it seeks to differentiate itself from Europe. This was again evident under the New Labour government, in which Tony Blair chose to emphasize the role of Britain as a bridge between Europe and America in his Chicago

\footnotetext{
73 Oliver Daddow, 'Global Britain: the discursive construction of Britain's post-Brexit world role', Global Affairs 5:1, 2019, p.15.

${ }^{74}$ Foreign Affairs Committee, 'Oral Evidence: Global Britain', HC780, 6 February, House of Commons, 2018, http://data.parliament.uk/writtenevidence/committeeevidence.svc/evidencedocument/foreign-affairscommittee/global-britain/oral/78065.html; and Foreign Affairs Committee, 'Oral Evidence: Global Britain', HC780, 27 February, House of Commons, 2018, http://data.parliament.uk/writtenevidence/committeeevidence.svc/evidencedocument/foreign-affairscommittee/global-britain/oral/79269.html.

75 Pauline Schnapper, 'The Labour Party and Europe from Brown to Miliband: Back to the Future?', Journal of Common Market Studies, 53:1, 2015, p. 159.

${ }^{76}$ Schnapper, 'The Labour Party' p. 159.
} 
foreign policy speech in 1999 , one in which the UK's value to the US lay in its role as an Atlanticist influence within the EU. As this suggests, there is much about Britain as an outward looking state that represents continuity rather than a new policy. As Sir Simon Fraser explained the term 'Global Britain' is being used to demonstrate that the UK 'will continue to be an outward-looking country that is seeking to be influential in the world, which is consistent with our previous foreign policy stance'. ${ }^{77}$ It is difficult to evidence what is 'new' in the idea of Global Britain and lack of clarity on what specific policies it might entail makes it difficult for the UK to sell Global Britain as a foreign policy strategy abroad.

Given that Global Britain is ambiguous in meaning and not distinctly different from earlier foreign policy platforms, some of which were grounded in appeals to empire, it's not surprising that its reception in New York has been underwhelming. At the United Nations, diplomats from outside the UK were in agreement that the policy of 'Global Britain' had little relevance or was simply not discussed in New York. ${ }^{78}$ As one interviewee highlighted, 'Other countries don't really talk about it much; they are more interested in what is the British policy on Africa or what is the British policy on the Middle East'.${ }^{79}$ Consequently, it was often characterized by diplomats as simply a slogan with very little behind it and was therefore 'much more about the UK domestic audience'. ${ }^{80}$ It is perhaps not surprising then that Theresa May nor Boris Johnson did not refer to 'Global Britain' in their speech to the UN General Assembly in 2018 and 2019. ${ }^{81}$

\section{The UK and Somalia}

Ambiguity over what 'Global Britain' means, or how it is new, suggests that it is instructive to look more closely at what the UK has been doing at the Council. As noted, the UK draws on

\footnotetext{
${ }^{77}$ Foreign Affairs Committee, 'Oral Evidence: Global Britain', HC780, 6 February, House of Commons, 2018, http://data.parliament.uk/writtenevidence/committeeevidence.svc/evidencedocument/foreign-affairscommittee/global-britain/oral/78065.html.

78 Author Interview \#13, conducted in New York, 27 July 2018.

${ }^{79}$ Author Interview \#10, conducted in New York, 26 July 2018.

${ }^{80}$ Author Interview \#8, conducted in New York, 25 July 2018.

81 Theresa May, 'PM Speech to the UN General Assembly: 26 September 2018'

https://www.gov.uk/government/speeches/pm-speech-to-the-un-general-assembly-26-september-2018; Boris Johnson 'PM Speech to the UN General Assembly: 24 September 2019' and https://www.gov.uk/government/speeches/pm-speech-to-the-un-general-assembly-24-september-2019
} 
its reputation for diplomatic competence to influence the Council's agenda and the working practice that enables this is called 'penholding'. As the Council's agenda grew more complex, working practices adapted and in the name of efficiency France, the US and the UK (permanent 3 or $\mathrm{P} 3$ ) began to take the lead in drafting resolutions and agreeing among themselves before putting them to other members of the Council. This practice has been criticized for deepening a 'negotiation and consultation gap', a criticism UK diplomats are aware of and have sought to address. ${ }^{82}$ Indeed, our interview data indicates that the UK is seen as one of the more consultative and trusted permanent members. The point here, however, is that this practice, and the manner in which the UK approaches it, enables the UK to influence the Council's agenda; and as noted the UK has led on many issues, including Somalia.

Since its establishment in 2007, the African Union Mission in Somalia has had several successes. As Paul Williams writes:

Its most important success was protecting Somalia's fledgling transitional and then federal governments. But it also degraded al-Shabab, certainly from the period of the movement's "golden age" around 2010 and pushed the militants' main forces from Mogadishu in 2011. AMISOM also helped expand humanitarian access and provided various forms of relief to significant numbers of Somalis. The mission also still provides the security foundation on which all other international actors depend in order to operate in Somalia. ${ }^{83}$

Without underestimating the ongoing challenges, it is right to acknowledge the relative success of the international community's efforts in Somalia, and to recognise the UK's role at the Security Council in shepherding through, as penholder, the various AMISOM mandates. This record reinforces the reputation for competence, which, as we have demonstrated, translates into further political capital and influence. Yet any attempt to frame this as a UK leadership success story would also have to acknowledge the manner in which it aligned its influence in New York to its influence in Brussels so that the mandates it negotiated in the UN were resourced in the main by the EU. In fact the EU provided over 1.6 billion Euros to support AMISOM since 2007, and in 2018 it funded 80

\footnotetext{
${ }^{82}$ https://www.securitycouncilreport.org/un-security-council-working-methods/pen-holders-and-chairs.php

${ }^{83} \mathrm{https} / / / \mathrm{www}$.cfr.org/blog/lessons-learned-somalia-amisom-and-contemporary-peace-enforcement
} 
percent of the missions costs through its Africa Peace Facility (APF). ${ }^{84}$ Whilst AMISOM has been supported by UN peacekeeping funds since 2009, which the UK contributes to, it was almost entirely reliant on EU funding. It is possible that this would not have been the case had the UK not been a member of the EU. As Alex de Waal put it:

\begin{abstract}
the disproportionate share of APF funding going to Somalia (rather than to French security priorities in the Sahel, Central African Republic and elsewhere) is possible insofar as the UK has a leading role within the EU. Therefore, after March [2019, the original date to leave the EU], it seems that the UK will be left holding the pen for Somali at the UN Security Council and possibly continuing to host Somali conferences in London, but insofar as any security is to be provided by international forces, the Foreign Secretary will have to go begging for leftovers in Brussels.
\end{abstract}

The UK's success in aligning EU resources to its priorities at the UN Security Council was also commented on by our interviewees. As a source from an EU country put it, the UK was 'actively using the EU to promote their own agendas internally in the UN'. ${ }^{85}$ In the case of Somalia, they promoted AU peace operations through the UN and then 'made the EU pay for it'. $^{86}$ Likewise, Angus Lapsley, Director of Defence and International Security at the FCO, highlights, Somalia as a good example of "how the UK has been able to encourage and sometimes push our European colleagues to get more involved in a part of the world that we recognized was important'. ${ }^{87}$ For this reason 'EU funding to AMISOM has been disproportionate given the other security concerns afflicting the continent'; 88 and the concern after Brexit is that 'the EU [will] focus much more on the Sahel while the members of the P3 disagree about how to address insecurity in Somalia'. ${ }^{89}$ The capacity to align actions

\footnotetext{
${ }^{84}$ Alex de Waal, Brexidiocy and Somalia, LSE Blogs 15 November 2018; Paul D. Williams, 'Paying for AMISOM: Are Politics and Bureaucracy Undermining the AU's Largest Peace Operation?', 2017, https://theglobalobservatory.org/2017/01/amisom-african-union-peacekeeping-financing/; Paul D. Williams, Fighting for Peace in Somalia: A history and analysis of the African Union Mission (AMISOM), 2007-2017, (Oxford: Oxford University Press, 2018), p.7.

${ }^{85}$ Author Interview \#9, conducted in New York, 26 July 2018.

${ }^{86}$ Author Interview \#9.

${ }^{87}$ Select Committee on the European Union, 'Brexit: Common Security and Defence Policy (CSDP) missions', 2018, http://data.parliament.uk/writtenevidence/committeeevidence.svc/evidencedocument/eu-externalaffairs-subcommittee/brexit-common-security-and-defence-policy-csdp-missions/oral/76699.html.

${ }^{88}$ Mahmood and Ani, 'Impact of EU Funding', p.7The

${ }^{89}$ Author Interview \#8.
} 
and priorities within the UN Security Council and the EU has therefore been strategically useful for the UK, which will have less capacity to promote its priorities in the EU after Brexit. Indeed, a P5 interviewee described the UK since the Brexit referendum as 'quieter on AMISOM issues [in the Security Council] than they have been in the past' ${ }^{9}{ }^{90}$

Brexit also makes it more difficult for the EU to continue this level of support. The UK provides almost 15 percent of the budget for the European Development Fund (EDF), which is used to support the APF; ${ }^{91}$ and without a UK voice in Brussels it is possible that EU priorities will be realigned so that they match French priorities. The point here, however, is this new dynamic in the UK-EU relationship also rebounds on the UK's standing as a competent permanent member of the UN Security Council that can not only draft resolutions but can also deliver the resources to make those resolutions successful. Obviously the UK can invest more of its national resources to support its leadership at the UN, and indeed Theresa May's government pledged 'over $f 7$ million of new UK funding to support the AU's peacekeeping mission in Somalia'. ${ }^{92}$ But replacing the level of EU resources that the UK has turned it back on by deciding to leave the EU is likely to be beyond what the Treasury will tolerate. If those resources are not found then the gap between UK diplomats writing the mandates and the states expected to implement them will widen further, making it even more difficult to protect its reputation and the influence that stems from that.

\section{The UK and Yemen}

The situation in Yemen is another area where the UK has taken on the penholding role within the Security Council. The civil war there has been ongoing since 2014 when the Houthi Shia Muslim rebel movement seized control of northern Saada province and neighbouring areas. The Houthis went on to take the capital Sanaa, forcing President Hadi into exile abroad. Fearing that these events favoured their regional rivals, especially Iran, Saudi Arabia and other

\footnotetext{
${ }^{90}$ Author Interview \#24. This could be due in part to less Security Council activity on Somalia, however the point here is that the practitioner interviewed drew the connection between less activism from the UK and Brexit.

${ }^{91}$ ICG, 'Time to Reset African Union-European Union Relations' 2017, https://d2071andvip0wj.cloudfront.net/255-time-to-reset-african-union-european-union-relations.pdf, p.6. 92 Theresa May, 'New UK Support to Boost Long-term Stability in Somalia', 2018, https://www.gov.uk/government/news/new-uk-support-to-boost-long-term-stability-in-somalia.
} 
mostly Sunni Arab states began air strikes against the Houthis, with the declared aim of restoring Hadi's government. ${ }^{93}$ A humanitarian crisis followed, with at least 8.4 million people at risk of starvation and 22.2 million people - $75 \%$ of the population - in need of humanitarian assistance, according to the UN. ${ }^{94}$ Secretary General Antonio Guterres described it as 'the world's worst humanitarian crisis'. ${ }^{95}$

In this context, UK leadership at the Security Council has been heavily criticized. In fact, the United Nations Association of the UK described it as 'absent', ${ }^{96}$ and others accused it of failing to live up to the values of the UN Charter. ${ }^{97}$ Recently the criticism focused on the strength of the Security Council response. Early in 2018, for instance, the Netherlands and Sweden advocated the need for a resolution on the humanitarian situation. At the same time, Kuwait sought a Council press statement in recognition of a new humanitarian relief plan that the Saudi Arabia-led coalition had announced on 22 January, known as the Yemen Comprehensive Humanitarian Operations. Facing these calls, the UK decided to move forward with a presidential statement. ${ }^{98}$ Such was the concern that the group of elected members pushing the UK for a stronger humanitarian commitment, which included Peru, Poland, Netherlands, Sweden, and Bolivia (sometimes joined by France), threatened to seize the pen if the UK continued to compromise. ${ }^{99}$

Of course, the UK was in a difficult position, and this was especially evident later in the year when, against the backdrop of peace talks in Sweden, the Council discussed proposed resolutions. In that instance, the US backed Saudi opposition to a UK proposal, ${ }^{100}$ and proposed instead that any resolution steer clear of humanitarian issues. ${ }^{101}$ A UK draft resolution did pass on 21 December 2018, and it insisted on a ceasefire and called for the implementation of the terms of the Stockholm Agreement, which was welcomed by aid

\footnotetext{
93 https://www.bbc.co.uk/news/world-middle-east-44466574

${ }^{94}$ https://www.bbc.co.uk/news/world-middle-east-44466574

95 António Guterres, 'Remarks to the pledging conference on Yemen', United Nations, 2018, https://www.un.org/sg/en/content/sg/speeches/2018-04-03/remarks-pledging-conference-yemen.

${ }^{96}$ Author Interview \#1.

${ }_{97}$ Author Interview \#14, conducted in New York, 27 July 2018.

98 https://www.whatsinblue.org/2018/03/yemen-security-council-presidential-statement.php

${ }^{99}$ Security Council Report, 'Yemen: Security Council presidential statement', 2018, https://www.whatsinblue.org/2018/03/yemen-security-council-presidential-statement.php. 100 https://www.theguardian.com/world/2018/nov/19/yemen-senior-houthi-rebel-calls-for-halt-to-attacks 101 https://www.whatsinblue.org/2018/12/security-council-to-vote-on-yemen-resolution.php
} 
agencies. ${ }^{102}$ However, the final resolution had been 'stripped of much of the language on guaranteeing humanitarian deliveries and the need for accountability for war crimes'. ${ }^{103}$ Faced with the prospect of a US veto, there was little scope for the UK to push the humanitarian agenda further than this. Had it done so, the Council may not have passed any resolution. It is interesting to note, however, that the UK compromise was interpreted as a reflection of its own national interests in the Gulf. This criticism is heard across a range of actors. Human Rights Watch, for instance, reminds us that the UK sold at least $£ 4.7$ billion worth of arms to Saudi Arabia since the escalation of the Yemen conflict in 2015, -104 and the House of Lords' Select Committee on International Relations argued that this relationship has 'narrowly' put the UK on the wrong side of international humanitarian law. ${ }^{105}$

How then does this relate to Brexit? Of course, the tension in UK foreign policy between the human rights and humanitarian agenda on the one hand, and the special relationship with the US and arms sales to the Gulf on the other is nothing new. ${ }^{106}$ When viewed through the prism of Brexit, however, our interviewees speculated that the balance of future UK foreign policy would favour commercial interests over liberal and humanitarian values more often, and the Yemen case was cited as an example. ${ }^{107}$ For instance, the UN's Assistant SecretaryGeneral for Human Rights Andrew Gilmour, stated that 'there is this perception [in the UN] that we [British] will just go and do deals with anybody because we are just so desperate to prove to the British people that they weren't lied to and that it was going to be trade deals all over the place, so we will not let human rights get in the way of our trade deals'. ${ }^{108}$ These concerns are amplified by reports that Britain has already received demands to roll back its

\footnotetext{
102 https://undocs.org/S/RES/2451(2018)

103 Julian Borger, 'UN agrees Yemen ceasefire resolution after fraught talks and US veto threat' The Guardian December 21, 2018.

${ }^{104}$ Human Rights Watch, 'Legal Challenge to UK Arms Sales to Saudi', 2018,

https://www.hrw.org/news/2018/11/05/legal-challenge-uk-arms-sales-saudis; also author Interview \#14; and Author Interview \#6, conducted in London, 18 June 2018.

105 Select Committee on International Relations, 'Yemen: Giving Peace a Chance', 2019, https://publications.parliament.uk/pa/ld201719/Idselect/ldintrel/290/29003.htm.

106 Nicholas J. Wheeler and Tim Wheeler, 'Good international citizenship: a third way for British foreign policy' International Affairs 74:4 (1998) 847-870.

107 Author Interview \#27; and Author Interview 2018 \#14.

108 Author Interview \#14. On this point, see also Champa Patel, 'Human Rights in the International System', Progressive Review, 25:1, 2018, p.13.
} 
human rights standards in exchange for progress on post-Brexit trade deals. ${ }^{109}$ Other examples where the UK is accused of rebalancing policy to the detriment of human rights include the Philippines, where a new defence memorandum was signed despite the International Criminal Court beginning investigations into alleged crimes against humanity in that country, ${ }^{110}$ and China, whose market will be even more valuable to UK business interests after it leaves the EU. ${ }^{111}$

Of course, it might be argued that a UK strategy oriented toward the pursuit of a narrower definition of the national interest, one that favours trade deals over leadership in the humanitarian and human rights field, does not make the UK less influential at the Security Council. The UK will be a permanent member regardless of the character of its global strategy post-Brexit; and, after all, the humanitarian and human rights community, including likeminded states, often criticizes China, Russia and the US but these states remain influential. UK strategy may be different after Brexit, this line of argument concludes, but it will not be less influential. We argue, however, that such a conclusion misunderstands the dynamics of the Council and the UK's structural relationship to them. The source of the UK's influence on the Council is very different to China, Russia and the US, who can threaten to use their vetoes without fear that such a tactic will rebound on their claim to a permanent seat. As noted, the UK and France, are not in that position. Their tactic in the Council is to write rather than block resolutions, taking the lead especially on the governance issues, including humanitarian and human rights, which have come to dominate the Council's agenda.

The UK is at the heart of Council matters, therefore, and it accrues political capital because it is committed to finding collective solutions to these problems. It is often the preferred penholder because it consults other states to persuade them, rather than to dictate positions that are formed around narrow national interests. The UK accrues capital and influence, in other words, not because it is a great power whose veto must be respected so that power is

\footnotetext{
109 Richard Partington, 'Post-Brexit trade partners ask UK to lower human rights standards' The Guardian, 13 February 2019, https://www.theguardian.com/politics/2019/feb/13/post-brexit-trade-partners-ask-uk-tolower-human-rights-standards

110 Joe Sandler Clarke, 'How Britain offered the murderous President Duterte materials for 'urban warfare", New Statesman, 11 May, 2018, https://www.newstatesman.com/politics/uk/2018/05/how-britain-offeredmurderous-president-duterte-materials-urban-warfare.

${ }^{111}$ Author Interview \#14; and Author Interview \#15.
} 
channeled through the Council, ${ }^{112}$ but because it is a competent and responsible member of the Council whose diplomats work tirelessly to find solutions to governance problems. Our findings indicate that a post-Brexit strategy that narrows the definition of the national interest will find this kind of activism more difficult because it devalues the political capital held by UK diplomats.

\section{Conclusion}

Unlike membership of the EU, the UK's permanent seat on the UN Security Council commands support from across the British political spectrum. It unites internationalists who see it as a significant platform for peacefully addressing global challenges, and nationalists who see it as recognition of the UK's great power status and ability to 'punch above its weight'. Where opinion divides is on the question of how Brexit impacts on the UK's status and influence at the UN and what is needed to protect that. Chris Muspratt, a researcher for the 'Get Britain Out' campaign group argued, for instance, that Brexit will enable the UK to defend its position against EU plans to replace the French and UK permanent seats with a single EU one. ${ }^{113}$ Others argue that Brexit compounds doubts about the identity of the UK as a 'great' power and calls into question the legitimacy of its permanent seat. ${ }^{114}$ Evidence pointing to the 'Europeanization' of the UK and France's permanent seat is scarce, ${ }_{-115}$ and the threat to the UK seat from this direction was, we suggest, exaggerated. Within the UN, however, Brexit is interpreted as a threat to the UK's influence because, as we have demonstrated here, membership of the EU helped the UK mobilize material resources to support the leadership positions its diplomats staked out at the Council.

This is the lesson of the Somalia case study discussed in this paper. EU membership helped the UK to achieve the influence expected of a great power despite the perception of post-war decline. As noted the government has recognized this point in respect of the particular

\footnotetext{
112 Ralph, Gifkins and Jarvis, 'The UKs Special Responsibility at the United Nations'.

${ }^{113}$ Arabella Lang, 'Brexit and the UN Security Council', House of Commons Library Briefing Paper, No.7597, 2016, http://researchbriefings.files.parliament.uk/documents/CBP-7597/CBP-7597.pdf

${ }^{114}$ See evidence by Whitman and Gegout in Lang 'Brexit and the UN'; Hill, 'Turning back the clock; Dee, and Smith, 'UK diplomacy at the UN'.

${ }^{115}$ Karen E. Smith, 'EU Member States at the UN: A Case of Europeanization Arrested? Journal of Common Market Studies 55:3, 2016.
} 
circumstances of the Somalia case; and more recently, it increased its commitment to UN operations, contributing a long-range reconnaissance group to the UN Multidimensional Integrated Stabilization Mission in Mali (MINUSMA). ${ }^{116}$ We posit that this increased material commitment will have to go further if it is to correct the perception in the UN that the UK will now no longer have a say on how the material resources of the much larger EU will be deployed.

A relationship between the UK's material contribution to the governance objectives of the UN and its diplomatic capital in that organization is clearly evident in our interview data, and was articulated most clearly with respect to international development aid. UK diplomats have much capital in this area because the commitment to spend $0.7 \%$ of gross national income in development aid puts the UK in good international standing. As one interviewee told us:

you can look at individual countries ... who have very high development spending and are held in high regard as a result and it's easier also for those countries to advocate for certain human rights policies in developing countries if they're backing it up with financial development support. If you don't do that and you're still trying to lecture you get less of a hearing. ${ }^{117}$

As our Yemen case illustrates too, there is a sense that as penholders on the Council, UK diplomats do wield influence because of their expertise in the conflict and humanitarian issue area, but if their pursuit of the national interest is seen to be unreasonable (i.e. on the wrong side of international humanitarian norms/rules) then it will be less trusted as a penholder. The attempt by a number of elected members, including EU member states, to take the pen on Yemen from UK diplomats may be a sign of future trends. It is not necessarily the case, of course, that post-Brexit Britain will risk its influence at the UN Security Council by cutting its commitment to peace operations and development aid, or by favouring trade deals over human rights. Yet our interview data suggests that at present there is a concern that this is what Brexit means. While 'global Britain' may indeed remain internationalist, the concern is

\footnotetext{
${ }^{116}$ Tim Ripley, UK to contribute long-range reconnaissance group to MINUSMA. Janes Defence Weekly 23 July 2019 at https://www.janes.com/article/90012/uk-to-contribute-long-range-reconnaissance-group-to-minusma ${ }^{117}$ Author interview \#11; also interview \#2 \#5 \#22
} 
it will also be more willing to compromise on its commitment to liberal values, and that will weaken its influence in those areas of the Council's business where it has been effective. 